\title{
THE USE OF APPROPRIATE VOCABULARY OF THE FIRST GRADE STUDENTS OF SMA NEGERI 6 KOTA BENGKULU
}

\author{
Novita Purnamasari \\ Bambang Suwarno \\ English Education Post- Graduate Program \\ University of Bengkulu \\ Email : echaecha.np@gmail.com
}

\begin{abstract}
The purpose of this study was to evaluate the use of appropriate vocabulary by the first grade students of SMAN 6 Kota Bengkulu. Population of this research was all of the first grade students of SMAN 6 Kota Bengkulu. They were 198 students. The number of the sample was taken $25 \%$ of the population. They were 50 students who were selected randomly. They were given a multiple choice vocabulary test with four choices. The result of this research showed that the vocabulary appropriateness by the first grade students of SMAN 6 Kota Bengkulu were as follows: deficient category was $6 \%$, mediocre category was $58 \%$, good category was $28 \%$, and very good category was $8 \%$. From the result of the study, it can be concluded that the vocabulary appropriateness by most of the first grade students of SMAN 6 Kota were in mediocre category. For further research, it is recommended to find out the factors that was faced the students in the use of appropriate vocabulary.
\end{abstract}

Keywords: Appropriate Vocabulary, First Graduate Students, SMA Negeri 6 Kota Bengkulu.

Abstrak: Penelitian ini bertujuan untuk mengevaluasi kesesuaian dalam penggunaan kosa kata bahasa Inggris pada siswa tingkat petama SMA Negeri 6 Kota Bengkulu. Populasi penelitian ini yaitu seluruh siswa tingkat pertama SMA Negeri 6 Kota Bengkulu. Jumlah sampel yaitu $25 \%$ dari populasi. Sampel tersebut dipilih secara acak dengan menggunakan teknik random sampling. Alat ukur yang dipakai yaitu tes kosa kata dengan bentuk pilihan ganda dengan empat pilihan. Dari hasil yang di dapat, dapat dilihat bahwa siswa yang tergolong kemampuannya kurang $6 \%$, cukup $58 \%$, baik $28 \%$, sangat baik $8 \%$. Dari hasil penelitian ini dapat disimpulkan bahwa kesesuaian dalam penggunaan kosa kata bahasa Inggris pada sebagian besar siswa tingkat pertama SMA Negeri 6 Kota Bengkulu adalah pada kategori cukup. Sangat dianjurkan untuk menemukan factor yang mempengaruhi kesesuaian dalam penggunaan kosa kata bahasa Inggris pada siswa.

Kata Kunci: Kesesuaian Kosa Kata, Siswa Kelas Pertama, SMA Negeri 6 Kota Bengkulu. 


\section{INTRODUCTION}

Vocabulary is a set of words, which can be used to build utterances or sentences. Ur (1996) defines vocabulary as the word that is taught in the foreign language, while Ricard (1992) says that vocabulary is a set of lexemes, including single words, compound words, and idioms.

Actually, vocabulary is an important aspect in language, because vocabulary serves as foundation to four language skills, namely listening, speaking, reading, and writing.

Besides, this is important for the students in developing their English, because basically, to master a language, the learner should master vocabulary. Nunan (1991) says that the students who have rich vocabulary succeed in learning English.

While Rivers in Nunan (1991), states that the acquisition of an adequate vocabulary is essential for successful second language use because without an extensive vocabulary, we will be unable to use the structures and functions we may have learned for comprehensible communication.

In addition by Zimmerman (in Coady and Huckin, 1998) states that vocabulary is central to language and critical importance to the typical learner. Without having enough vocabulary, the students will get difficulties in communicating their ideas orally and in writing. It means that vocabulary is the key to the mastery of English skills.

The Report of the National Reading Panel (2000) concluded, "The importance of vocabulary knowledge has long been recognized in the development of reading skills. As early as 1924, researchers noted that growth in word knowledge." While Fauziati (2005) says that vocabulary is central to language and of critical importance to typical language learner.

Without a sufficient vocabulary, one cannot communicate effectively or express his ideas in both oral and written forms. It means that we must master English vocabulary and its grammatical rules to make good communication to the other people.

The GBPP SMA (Senior High School) states that by the end of the third year, the students should have a sufficient capability in four language skills (reading, listening, speaking and writing). While there are 500 words that students should have mastered for the first year, 500 words for the second year and 500 words for the third year.

After graduation from the SMP (Junior High School), the students expected to master 1.000 words. Thus, the Senior High School students should have mastered of about 1.500 English words when they graduated from the Senior High School plus 1.000 words, which comes to 2500 words.

Furthermore, some theses that researcher had reviewed are concerned on mastery vocabulary. The results of their research were also different, depend on their research object. So what about students' mastery on the use of appropriate vocabulary? The use of vocabulary itself, depend on the context. 
As you begin to improve your vocabulary, it is very important for you to learn when and how to use it. Knowing a large word is not enough to showcase your skill. You must also be able to know when and how that word should be used. If you use the word in the wrong way, it may not make sense, or it could be taken out of context. It is also important for you to know your audience, and be familiar with the type of vocabulary they will be able to identify with. Once you understand this, you will be able to adjust your words to suit the situation. To enhance your selection of words, you should make it your goal to learn a new word each day.

Have you ever heard someone use a fancy word, but you could tell that they didn't know how to use it? This can be quite humiliating. One thing that I must emphasize to you is that using a fancy word improperly is just as bad as having poor grammar. When you do this, it becomes apparent that you are trying to sound intelligent and well informed, and people will be able to see through you like glass.

If you don't know how to use a word properly, it is best for you not to use it all. You will save yourself a lot of headaches and humiliation. If you use fancy words improperly, some people will correct you, and this can be one of the most embarrassing situations you can find yourself in.

We may think that we already know these words. But, can we use them? When the researcher was on practice of field experience at the first grade students of
SMA Negeri 6 Kota Bengkulu, researchers and also some English teachers there, found several mistakes made by students in the use of vocabulary. For example, when the students were asked to write a procedure text about how to make a cake, they often use the word burn, whereas they could use bake to indicate baking the cake. To become a master at using your vocabulary properly, you must know when to use words, and when not to use them.

According to the reason above, the researcher wants to investigate the use of appropriate vocabulary of the first grade students of SMA Negeri 6 Kota Bengkulu through descriptive method.

\section{METHODOLOGY}

This study used an evaluation research. According to Gay (1990), an evaluative study is the systematic process of collecting and analyzing data in order to make decisions. This research was an approach that discuss and discribe the problem which researcher experience itself, to know whether experts opinions were true or not.

This study was analyzed evaluatively through testing. The subject of this study concerned on the use of appropriate vocabulary of the first grade students of SMA Negeri 6 Kota Bengkulu in the 20092010 Academic Year.

The population of this study consisted of all first grade students of the SMA Negeri 6 Kota Bengkulu, in the 2009- 2010 academic year. The total populations were 198 students. This school was choosen because the researcher was on practice of field experience at that school. Sampling is 
the process of selecting a number of individuals for a study in such a way that the individuals represent the larger group from which they were selected. According to Arikunto (2006), when the subject is less than 100 , preferably taken all, so the research is the study population.

However, if large number of subjects, can be taken between $10-15 \%$ or $20-25 \%$ or more. The sample of this study was choosing based on the random sampling technique. The sample consists of $25 \%$ from the population. From the total population of 198 students, 50 students were taken as sample (see table). The distribution of population and sample could be described in the table below:

Table 1: The Distribution of Population and Sample

\begin{tabular}{|c|c|c|c|}
\hline No. & Class & Population & Sample \\
\hline 1. & XA & 32 & 8 \\
\hline 2. & XB & 32 & 9 \\
\hline 3. & XC & 34 & 9 \\
\hline 4. & XD & 34 & 8 \\
\hline 5. & XE & 32 & 8 \\
\hline 6. & XF & 34 & $\mathbf{5 0}$ \\
\hline
\end{tabular}

The instrument of this research was an achievement test in multiple choice forms which was written by the researcher to find out the use of appropriate vocabulary of the first grade students of SMA Negeri 6 Kota Bengkulu.

It was developed on the basis of the Senior High School English vocabulary in the English syllabus. The items of the test were tried out to 20 students who did not belong to the sample. The try out was conducted to determine the validity and the reliability of the test items.

The try out procedure was as follow:
1. The test draft was tested on 20 students.

2. The students were asked to answer the test item.

3. The students' score were arranged from the highest to the lowest, $1^{\text {st }}$ to $10^{\text {th }}$ ranks formed to upper group while $11^{\text {th }}$ to $20^{\text {th }}$ ranks formed to lower one.

4. The facility value and discrimination index for each item was calculated.

To know the validity of the instrument, the researcher was used the procedure for measuring the felicity value and discrimination index (Heaton, 1997). The formula was as follow: 


$$
H^{\prime} V=\frac{\mathrm{U}+\mathrm{L}}{2 \mathrm{n}}, \quad D i=\frac{\mathrm{U}-\mathrm{L}}{\mathrm{n}}
$$

Where:

FV : Felicity Value

DI : Discrimination Index

$\mathrm{U}$ : The correct answer of the upper group

L : The correct answer of the lower group

$\mathrm{n}$ : The number of each group

Heaton suggests to accepting items with facility value between 0,3 and 0,7 while discrimination index between 0,3 and $+1,02$.

The reliability of the test items was found by the K - R.21 formula (Gay, 1991):

$$
K R=\frac{k(S D)^{2}-X(k-X)}{(S D)^{2}(k-1)}
$$

Where:

$\mathrm{k}$ : The number of items in the test SD : Standard deviation
$\bar{X} \quad$ : Mean

The test score were analyzed by using the general formula bellow:

$$
\mathrm{w}=\frac{X}{\bar{Y}} \times \mathbf{R}
$$

Where:

W : Weighted score or score obtained

$\mathrm{X}$ : Number of the true answer

$\mathrm{Y}$ : Total number of the item test

$\mathrm{R}$ : Range of the score

Sudjana (2009) suggests that, in order to make classification, the total range were divided into some lower level range that decided in advance. The total range is $\mathbf{5 0 0}$ words.

If 5 range levels are used, the same interval for each level is:

$$
i=\frac{\mathbf{5 0 0}}{\mathbf{5}}=100
$$

The table of range levels will be constructed as follows:

Table 2: Score Criteria

\begin{tabular}{|c|c|}
\hline Range & Qualification \\
\hline $401-500$ & Very Good \\
\hline $301-400$ & Good \\
\hline $201-300$ & Mediocre \\
\hline $101-200$ & Deficient \\
\hline $0-100$ & Strongly Deficient \\
\hline
\end{tabular}

(Sudjana, 2009) 
Based on the data, the researcher also makes the distribution of students' answer in types of vocabulary in order to find out which types of vocabulary that was difficult for the students.

\section{RESULT}

The items of test were tried out to the first grade students of SMA Negeri 6 Kota Bengkulu in 2009 - 2010 Academic year. The participants of the try out items test were 20 students. The try out was conducted to determine the validity and the reliability of the test items. Try-out result consisted of verification of validity, item characteristics and reliability.

To know the validity of the instrument, the researcher used the procedure for measuring the felicity value and discrimination index. While Heaton (1988) suggests to accepting items with felicity value between 0,3 and 0,7 and discrimination index between 0,3 and $+1,02$.

The researcher found only 60 out of 100 items with felicity value between 0,3 and 0,7 and discrimination index between
0,3 and $+1,02$. It means that 60 items were valid and 40 items were not valid. 50 items were taken for the instrument of the research.

The reliability of the test items was found by the K-R.21 formula (Gay, 1991). According to Gay, the reliability was acceptable 0, 900 ( $\mathrm{r}>=0,900)$. The reliability index of the passed items was 1 , 01.

The results of this research were divided into two main points, there were the result of students' vocabulary appropriateness in five category qualifications namely very good, good, mediocre, deficient, and strongly deficient; and the second was students mastery of vocabulary in different classificasions of vocabulary namely noun, verb, preposition, adjective, and adverb.

After collecting and analyzing the data, the researcher presented result of students' vocabulary appropriateness in five category qualifications namely very good, good, mediocre, deficient, and strongly deficient. The result could be seen as follow:

Table 3: The Result of Students' Vocabulary Appropriateness in Five Categories

\begin{tabular}{|c|c|c|}
\hline Category & Frequency & $\%$ \\
\hline Very good & 4 & $8 \%$ \\
\hline Good & 14 & $28 \%$ \\
\hline Mediocre & 29 & $58 \%$ \\
\hline Deficient & 3 & $6 \%$ \\
\hline
\end{tabular}




\begin{tabular}{|c|c|c|}
\hline Strongly deficient & - & - \\
\hline Total & $\mathbf{5 0}$ & $\mathbf{1 0 0} \%$ \\
\hline
\end{tabular}

From table 3, could be seen the total scores of the sample. The result of students' vocabulary appropriateness by the first grade students of SMAN 6 Kota Bengkulu in 2009/2010 Academic year was $8 \%$ was in very good category, $28 \%$ was in good category, $58 \%$ in Mediocre category, $6 \%$ was in deficient category, and there was no students were in strongly deficient category.

After collecting and analyzing the data, the researcher presented result of students mastery of vocabulary in different classificasions of vocabulary namely noun, verb, preposition, adjective, and adverb. The result could be seen as follow:

Table 4: The Result of Students' Mastery in Different Classification of Vocabulary

\begin{tabular}{|c|c|c|c|}
\hline \multirow{2}{*}{$\begin{array}{c}|c| \\
\text { Classification of } \\
\text { Vocabulary }\end{array}$} & $\begin{array}{c}|c| \\
\text { Frequency of True } \\
\text { Answer }\end{array}$ & $\begin{array}{c}\text { Total } \\
\text { Frequency of False } \\
\text { Answer }\end{array}$ & \\
\cline { 2 - 3 } & $36(72 \%)$ & $14(28 \%)$ & $50(100 \%)$ \\
\hline Noun & $34(68 \%)$ & $16(32 \%)$ & $50(100 \%)$ \\
\hline Verb & $31(62 \%)$ & $19(38 \%)$ & $50(100 \%)$ \\
\hline Preposition & $18(36 \%)$ & $32(64 \%)$ & $50(100 \%)$ \\
\hline Adjective & $27(54 \%)$ & $23(46 \%)$ & $50(100 \%)$ \\
\hline Adverb & & & \\
\hline
\end{tabular}

From table 4, could be seen the distribution of students answer in types of vocabulary, namely noun, verb, preposition, adjective, and adverb. The result of students answer in types of vocabulary by the first grade students of SMAN 6 Kota Bengkulu in 2009/2010 Academic year, in noun type of vocabulary, there were 36 students (72 $\%)$ could be answered true, while 14 students $(28 \%)$ were answer false. In verb type of vocabulary, there were 34 students (68\%) could be answered true, while 16 students $(32 \%)$ were answer false. In preposition type of vocabulary, there were 31 students (62\%) could be answered true, while 19 students ( $38 \%$ ) were answer false. In adjective type of vocabulary, there were 18 students (36\%) could be answered true, 
while 32 students (64\%) were answer false. In adverb type of vocabulary, there were 27 students (54\%) could be answered true, while 23 students $(46 \%)$ were answer false.

From the result, it could be concluded that most students found difficulty in adjective type of vocabulary.

\section{DISCUSSION}

After the data had been calculated and analyzed, the result of students' vocabulary appropriateness by the first grade students of SMAN 6 Kota Bengkulu in 2009/2010 Academic year was $58 \%$ in mediocre category, $28 \%$ was in good category, $8 \%$ was in very good category, $6 \%$ was in deficient category, and there was no in strongly deficient category.

Furthermore, the result of students answer in types of vocabulary by the first grade students of SMAN 6 Kota Bengkulu in 2009/2010 Academic year, in noun classification, there were 36 students $(72 \%)$ could be answered true, while 14 students (28\%) were answer false.

In verb classification, there were 34 students (68\%) could be answered true, while 16 students (32\%) were answer false. In preposition classification, there were 31 students $(62 \%)$ could be answered true, while 19 students (38\%) were answer false.

In adjective classification, there were 18 students (36\%) could be answered true, while 32 students (64\%) were answer false.

In adverb classification, there were 27 students (54\%) could be answered true, while 23 students (46\%) were answer false.

From the result, it could be concluded that most students found difficulty in adjective type of vocabulary. The average score was 33.95 with standard deviation of 235.84 .

The result in the use of appropriate vocabulary, because the students' were good or good enough in the use of appropriate vocabulary depends on the context.

If the researcher sort the result from the largest to the smallest amount of students, at the first position there are 29 students (58 $\%$ ), they were in mediocre qualification. Mediocre means the students vocabulary appropriateness were in moderate position. While according to Cambridge Advanced Learner's Dictionary, mediocre means not very good.

On the informal observation, students in mediocre qualification is still difficult to distinguish a few vocabularies, but they can overcome these difficulties by guessing the meaning of these words depends on the context.

At the second position, there were 14 students $(28 \%)$ in good qualification. At the third position there were 4 students ( 8 $\%$ ) in very good qualification. Good and very good qualification indicates that they were good enough in the use of vocabulary especially that is related to the choice of vocabulary as the appropriateness of vocabulary in their context, appropriate of vocabulary and another, and appropriate of vocabulary with a topic. And the last, the smallest amount of students were three students or $6 \%$ in deficient qualification.

Deficient qualification means their ability in vocabulary appropriateness is still 
lack. They were still find difficulties in the use of vocabulary especially that is related to the choice of vocabulary as the appropriateness of vocabulary in their context, appropriate of vocabulary and another, and appropriate of vocabulary with a topic.

There were 47 students who occupied mediocre to very good qualification. Based on informal interview with some students from those students, they were like English. It means that they were having motivation in learning English.

On the other side, they were three students in deficient qualification. Based on an informal interview with those students, the researcher knew that they were unserious in learning English. It was happen because they think that study English is not useful for them.

Besides, they usually fell bored in learning English, lack in practicing, and less in doing exercises. In conclusion, the students who have motivation in learning English will be better in English ability. And most of the first grade students of SMAN 6 Kota Bengkulu in the 2009- 2010 Academic year were achieved mediocre category.

\section{CONCLUSION}

Based on all facts presented in the previous chapters, the use of appropriate vocabulary by the first grade students of SMAN 6 Kota Bengkulu in 2009/2010 Academic year was $58 \%$ in mmediocre category, $28 \%$ was in good category, $8 \%$ was in very good category, $6 \%$ was in deficient category, and there was no in strongly deficient category.
The average score was 33.95 with standard deviation of 235.84. The result in the use of appropriate vocabulary, because the students' were good or good enough in the use of appropriate vocabulary depends on the context. Furthermore, the result of students answer in types of vocabulary by the first grade students of SMAN 6 Kota Bengkulu in 2009/2010 Academic year, in noun type of vocabulary could be concluded that most students have found difficulty in adjective type of vocabulary with 18 students $(36 \%)$ were answered true and 32 students $(64 \%)$ were answer false.

Based on informal interview with some students from those students, they were like English. It means that they were having motivation in learning English. On the other side, they were three students in deficient qualification.

Based on an informal interview with those students, the researcher knew that they were unserious in learning English. It was happen because they think that study English is not useful for them. Besides, they usually fell bored in learning English, lack in practicing, and less in doing exercises. In conclusion, the students who have motivation in learning English will be better in English ability. But in conclusion, the students who have motivation in learning English will be better in learning english, especially vocabulary than the students who have no motivation in learning English.

There were some suggestions, the first one for English teachers in SMAN 6 Kota Bengkulu. The teachers must develop a good technique for teaching vocabulary, 
they should find better ways to teach vocabulary in order to motivate the students to learn vocabulary themselves.

The teachers also should be taught the words in context, because the meaning of certain words change according to their use in particular sentence. Furthermore, the teacher also should be pay more attention in teaching adjective, because most of the students have found difficulty in this type of vocabulary.

English books and dictionaries should be added continually in the library, which can be used by the students to support learning English. Besides, important facilities sch as language laboratory, teaching media, etc, should be available at school in order to improve students ability of vocabulary.

Another suggestion was for the students. They should study hard in developing their English, especially in vocabulary. The students can do some vocabulary learning strategies, such as: contextualisation, elaboration, inferencing, translation, personalisation, keeping own dictionary or vocabulary book, and grouping the vocabulary.

Besides, they should be give more time in practicing and doing exercises in order to increase their vocabulary ability. Besides, the students should be pay more attention in adjective, in order to improve their vocabulary ability.

For further researcher, they need to be conducted other research to find out the factors that was faced the students in the use of appropriate vocabulary and with different type of schools, for example, vocational school.

Further research can examine the appropriate vocabulary depend on the majors at that school or other school.

\section{REFERENCES}

Arikunto, Suharsimi. (2006). Prosedur Penelitian. Jakarta:Rineka Cipta.

Astuti, Eliya. (2003). The Mastery of the SMU English Vocabulary by the third year Students of the SMUN 1 Pondok Kelapa Bengkulu Utara In 2002/2003 Academic Year. Unpublished Thesis

Bengkulu: Universitas Bengkulu.

Demos. (2010). Appropriate in Vocabulary. http://www.exforsys.com/career-center. accessed on June 12, 2010.

Franklin, H B et. al. (1990). Vocabulary in Context. Jakarta: Binarupa Aksara.

Gay, L. R. (1990). Educational Research. Singapore : Macmillan Publishing Company.

Hadisubroto. (2008). English Usage. Surabaya: Indah. Hatch, Evelyn and Cheryl Brown. (1998). Vocabulary, Semantics, and Language Education. Australia : Cambridge University Press.

Heaton, J. B. (1997). Writing English Language Test. New York: Longman Inc.

Jennie. (2010). Beginning Vocabulary Acquisition. http:/ielanguages.com/blog/index.php. accessed on May 26, 2010.

Laufer, Batia. (2010). A Problem in Vocabulary Learning. http://litj.oxfordjournals.org. Accessed on May 26, 2010.

Len, Evelyn and Yue. (1988). Secondary Vocabulary Guide and Practice. Singapore : Preston Corporation.

Nation, Paul and Robert Waring. (2002). Vocabulary Size, Text Coverage and Word Lists. 
http://www.fltr.ucl.ac.be/fltr/GERM/ETAN/bibs/ vocab/cup.html. accessed on February 8, 2010.

Nation, Paul. (1990). Teaching and Learning Vocabulary. Boston: Heinle and heinle.

Nunan, David. (1995). Language Teaching Methodology (Teaching Vocabulary). Ner York: Macmilan.

Pikulski, John and Shane Templeton. (2004). Teaching and Developing Vocabulary. www. Edu place. com. accessed on February 8, 2010.

Priyasudiarja, Yusup. (2007). Frequently Confused English. Yogyakarta: Kanisius.

Rini, Ayu. (2009). Complete English Words. Jakarta : Papas Sinar Sinanti.
Rogerson, H D et. al. (1995). Words for Students of English. Jakarta: Binarupa Aksara.

Solahudin, M. (2008). The Great Problems in English. Yogyakarta: Diva Press.

Sudjana, Nana. (2009). Penilaian Hasil Proses Belajar Mengajar. Bandung : Remaja Rosdakarya.

Susatyo, S T. (2003). Dictionary of Frequent Errors for Indonesian Users. Bandung: YramaWidya. Ur, Penny. (1996). A Course in Language Teaching. United Kingdom: Cambridge University Press.

Yuspita, Aprideni. (2003). The Mastery of English Vocabulary by the third year Students of the SMU Negeri 1 Mukomuko in the 2002- 2003 Academic Year. Unpublished Thesis Bengkulu : Universitas Bengkulu. 